Manufacturing and Management Paradigms, Methods and Tools for Sustainable Industry 4.0-Oriented Manufacturing Systems

\author{
Leonilde Varela $^{1, * \mathbb{D}}$, Paulo Ávila ${ }^{2}$, Hélio Castro ${ }^{2} \mathbb{D}$, Goran D. Putnik ${ }^{1}$, Luís Miguel Ciravegna Fonseca ${ }^{3} \mathbb{D}$ \\ and Luís Ferreira ${ }^{4}(\mathbb{D}$
}

1 Department of Production and Systems, School of Engineering, and Algoritmi Research Center, University of Minho, 4804-533 Guimarães, Portugal; putnikgd@dps.uminho.pt

2 School of Engineering, Polytechnic of Porto, and INESC TEC, 4249-015 Porto, Portugal; PSA@isep.ipp.pt (P.Á.); hcc@isep.ipp.pt (H.C.)

3 School of Engineering and CIDEM Research Center, Polytechnic of Porto, 4249-015 Porto, Portugal; lmf@isep.ipp.pt

4 Polytechnic Institute of Cávado e Ave, School of Technology, Lugar do Aldão, 4750-810 Vila Frescainha S. Martinho-Barcelos, Portugal; lufer@ipca.pt

* Correspondence: leonilde@dps.uminho.pt

Citation: Varela, L.; Ávila, P.; Castro, H.; Putnik, G.D.; Fonseca, L.M.C.; Ferreira, L. Manufacturing and Management Paradigms, Methods and Tools for Sustainable Industry 4.0-Oriented Manufacturing Systems. Sustainability 2022, 14, 1574. https://doi.org/10.3390/ su14031574

Received: 10 January 2022 Accepted: 11 January 2022 Published: 29 January 2022

Publisher's Note: MDPI stays neutral with regard to jurisdictional claims in published maps and institutional affiliations.

Copyright: (C) 2022 by the authors. Licensee MDPI, Basel, Switzerland. This article is an open access article distributed under the terms and conditions of the Creative Commons Attribution (CC BY) license (https:// creativecommons.org/licenses/by/ $4.0 /)$.
In the current Industry 4.0 era (I4.0, for short) [1-3], manufacturing and management (M\&M) paradigms, methods and tools should be wisely developed to fulfil sustainability issues, regarding not just economic but also social and environmental concerns by simultaneously fostering organizational efficiency excellence and transformational initiatives, therefore contributing to enduring business results [4].

Collaboration is an important paradigm that implies an interaction between two or more entities. They co-learn [5-8], thus being of utmost importance to reach the sustainability requisites stated, particularly in the I4.0. In the context of collaborative M\&M, this paradigm is applicable between any two or more entities, which includes not just common manufacturing resources or machines $(\mathrm{M}-\mathrm{M})$ but also humans $(\mathrm{H}-\mathrm{H})$ and their interaction with the machines (H-M) [6].

The I4.0 is characterized by a widened set of other paradigms, methods and tools that can promote sustainability in manufacturing systems, with flexibility as one important aspect [9]. However, this flexibility cannot just arise directly from the flexibility underlying the manufacturing resources but also from other perspectives, namely through the flexibility subjacent to the manufacturing systems itself, while enabling quick adaptation of the production under dynamically varying conditions. These requisites arise either internally, in the factories, or from the outside, namely regarding the need to fulfil the customers' expectations or needs [5,9-12].

Although not new, the simulation technique has also been gaining a refreshed importance nowadays in the I4.0, being one of its main pillars [13-15]. Simulation is a very versatile technique that enables the implementation of different methods by using various software and tools, which can be easily adapted to the specific needs of the manufacturing systems $[13,15]$. One such need consists of supporting manufacturing management $[13,15-17]$ to reach appropriate solutions in manufacturing systems, varying from make-to-stock (MTS) to make-to-order (MTO) production philosophies, such as engineerto-order (ETO) and design-to-order (DTO). In this regard, advanced simulation, along with other management approaches and systems, for instance, based on game theory, and other advanced and integrated optimization approaches, namely for chaos and complexity management, based on distributed, collaborative, and real-time management principles, are of upmost importance nowadays, in the I4.0 [18,19].

In the context of I4.0, another important issue starts with the capability of designing smart products and advanced materials, and/or production systems based on concurrent 
and collaborative engineering, e.g., on open design and advanced design theory. In this regard, metatheory, formal theories, and formalisms, along with learning organization principles, organizational semiotics, and standards, are relevant nowadays [19].

The cyber physical (production) systems (C[P]PS) and smart factories, based on intelligent sensing systems, open systems, and networked and distributed manufacturing systems, as well as urban production systems, along with virtual organizations and open systems, do also play fundamental roles nowadays [13,18,20-22]. In such advanced manufacturing systems, integration, distributivity, virtuality, agility, servitization, digitalization, and decentralization are also major issues in sustainable and collaborative processes and practice in the I4.0. In this regard, the (Industrial) internet of things ([I]IoT), smart and ubiquitous networks based on the cloud, enable large and complex networks and their digitalization $[10,11,23,24]$. Decisions and related actions must be taken quickly and are supported by accuracy monitoring systems [25].

Cloud-based computing, manufacturing and management are thus fundamental currently for fully proving enhanced flexibility and suitability for enabling collaboration and effective engineering practice $[6,10]$. Cumulatively, horizontal and vertical integration among partners, factories, suppliers, customers, and other businesses and/ or stakeholders is also crucial in the current I4.0 era [5].

Additive manufacturing or 3D printing also consists of other critical enabling technology and principles for promoting collaborative processes and practices between stakeholders in networked manufacturing environments. Moreover, exponential technology and advanced processes, high-performance computing, and disruptive technologies (e.g., automation and robotics, autonomous and collaborative robots, advanced mechatronics, micro and nano manufacturing, and supercomputing) are also key enablers for sustainable manufacturing and management in the current I4.0 context.

Advanced interfaces, virtual and augmented reality, and digital twin, promoting and enhancing collaboration between entities, are also critical today. These technologies enable advanced and integrated decision support systems (DSS) and databases (DB), knowledge engineering and knowledge bases $(\mathrm{KB})$, automatic data acquisition, and a semantic web for enhancing collaboration.

There are also other relevant approaches, methods, and techniques in the I4.0, for instance, based on artificial intelligence, e.g., machine learning and deep learning, pattern recognition, blockchain, and other technologies and methodologies for enabling and enhancing manufacturing and management [21,22]. In addition, business intelligence, big data, and data analytics in the specific data science domain are essential pillars of I4.0 [26].

Moreover, it is also of utmost importance to explore new business and organizational models, attending to the need inherent to the circular economy, finance, and risk management in and between organizations [27]. That can support organizations simultaneously managing the present and transforming for the future while responding to the challenges and opportunities of changing business environments [28]. The organizational change and transformation are now mandatory, regarding employees, their competencies, and culture, to reach suitable manufacturing and management [27]. For industry, the management of I4.0 it is a crucial issue and should also be carried out considering factors of production, directly or indirectly, in order to improve their performance [29].

All these issues are crucial for enabling advanced, integrated, and intelligent supply networks, projects, businesses, and their integrated and fully supported management, to reach manufacturing and management while ensuring high-quality standards, extended to other practices, e.g., maintenance and control [4]. To this end, several different kinds of performance measures and goals should be considered to reach sustainability, organizational and machine robustness, scalability systems, and other advanced enterprise information systems (EIS), such as enterprise resource planning (ERP), manufacturing execution systems (MES), and systems for supply chain management (SCM).

This Special Issue aims to provide new insights regarding manufacturing or management paradigms (strategies), methods, tools, and practices aligned with the contemporary 
necessity to create and implement sustainable I4.0 manufacturing systems. Each of the five selected papers of this Special Issue makes a novel contribution to that aim.

Samala et al. present a job adjustment strategy for predictive maintenance in semi-fully flexible systems based on machine health status to reduce simultaneous machine failures, improve the average occurrence of the first failure time of machines, and decrease the loss of production.

Silva et al. present a decision-making tool based on a simulation model to support the production of knits and damask fabrics that significantly increase production rates and reduce waiting time.

Xiong et al. study the optimal production planning in a hybrid MTS and MTO production system for a single product under the cap-and-trade environment, providing optimal production decision and carbon trading decision for the manufacture case study under a cap-and-trade environment.

Zrelli et al. research the extent and nature of productivity growth in manufacturing industries using nonparametric frontier techniques by applying the output-oriented Malmquist productivity index method for 34 Tunisian manufacturing industries over 2002-2016.

Oláh et al. represent Industry 4.0 and its technologies, which are integrated with sustainable development goals, to promote a sustainable Industry 4.0, combining environmental protection and sustainability.

Undertaking this Special Issue, Manufacturing and Management Paradigms, Methods and Tools for Sustainable Industry 4.0-oriented Manufacturing Systems, was a challenging and rewarding task for the Editors. The diversity of the manuscripts demonstrates the broad scope and relevance of the research theme in fostering performance and transformation to achieve sustainable and enduring outcomes.

\section{List of Contributions:}

1. Samala, T., Manupati, V.K., Nikhilesh, B.B.S., Varela, M.L.R., \& Putnik, G. (2021). Job adjustment strategy for predictive maintenance in semi-fully flexible systems based on machine health status.

2. Silva, V., Ferreira, L.P., Silva, F.J., Tjahjono, B., \& Ávila, P. (2021). Simulation-Based Decision Support System to Improve Material Flow of a Textile Company.

3. Xiong, S., Feng, Y., \& Huang, K. (2020). Optimal MTS and MTO Hybrid Production System for a Single Product Under the Cap-And-Trade Environment.

4. Zrelli, H., Alsharif, A.H., \& Tlili, I. (2020). Malmquist Indexes of Productivity Change in Tunisian Manufacturing Industries.

5. Oláh, J., Aburumman, N., Popp, J., Khan, M.A., Haddad, H., \& Kitukutha, N. (2020). Impact of Industry 4.0 on environmental sustainability.

Author Contributions: Conceptualization, L.V., P.Á., H.C. and G.D.P.; methodology, L.V., P.Á., H.C. and G.D.P.; writing—original draft preparation, L.V., P.Á., H.C., L.M.C.F. and L.F.; writing, L.V., P.Á., H.C., L.M.C.F. and L.F.; review and editing, L.V., P.Á., H.C., L.M.C.F., L.F. and H.C. All authors have read and agreed to the published version of the manuscript.

Funding: This work was supported by national funds through the FCT—Fundação para a Ciência e Tecnologia through the R\&D Units Project Scopes: UIDB/00319/2020, UIDB/50014/2020, and EXPL/EME-SIS/1224/2021.

Institutional Review Board Statement: Not applicable.

Informed Consent Statement: Not applicable.

Conflicts of Interest: The authors declare no conflict of interest. 


\section{References}

1. Finance, A.T.C.C. Industry 4.0 Challenges and solutions for the digital transformation and use of exponential technologies. Financ. Audit. Tax Consult. Corp. Zur. Swiss 2015, 1-12.

2. Hankel, M.; Rexroth, B. The reference architectural model industrie 4.0 (rami 4.0). ZVEI 2015, 2, 4-9.

3. Xu, L.D.; Xu, E.L.; Li, L. Industry 4.0: State of the art and future trends. Int. J. Prod. Res. 2018, 56, 2941-2962. [CrossRef]

4. Fonseca, L.; Amaral, A.; Oliveira, J. Quality 4.0: The EFQM 2020 Model and Industry 4.0 Relationships and Implications. Sustainability 2021, 13, 3107. [CrossRef]

5. Arrais-Castro, A.; Varela, M.L.R.; Putnik, G.; Ribeiro, R.; Dargam, F. Collaborative negotiation platform using a dynamic multi-criteria decision model. Int. J. Decis. Support Syst. Technol. 2015, 7, 1-14. [CrossRef]

6. $\quad$ Ferreira, L.; Punik, G.; Varela, L.; Manupati, V.K.; Lopes, N.; Cunha, M.; Alves, C.; Castro, H. A Framework for Collaborative Practices Platforms for Humans and Machines in Industry 4.0 oriented Smart and Sustainable Manufacturing Environments. In Smart and Sustainable Manufacturing Systems for Industry 4.0; Manupati, V.K., Goran, D.P., Rocha, M.L., Eds.; CRC Press, Taylor \& Francis Group: Boca Raton, FL, USA, 2022; in press.

7. Putnik, G.D.; Putnik, Z.; Shah, V.; Varela, L.; Ferreira, L.; Castro, H.; Catia, A.; Pinheiro, P. Collaborative Engineering: A Review of Organisational Forms for Implementation and Operation. In IOP Conference Series: Materials Science and Engineering; IOP Publishing: Bristol, UK, 2021; Volume 1174, p. 012028.

8. Putnik, G.D.; Putnik, Z.; Shah, V.; Varela, L.; Ferreira, L.; Castro, H.; Catia, A.; Pinheiro, P. Collaborative Engineering definition: Distinguishing it from Concurrent Engineering through the complexity and semiotics lenses. In IOP Conference Series: Materials Science and Engineering; IOP Publishing: Bristol, UK, 2021; Volume 1174, p. 012027.

9. Reddy, M.S.; Ratnam, C.; Agrawal, R.; Varela, M.L.R.; Sharma, I.; Manupati, V.K. Investigation of reconfiguration effect on makespan with social network method for flexible job shop scheduling problem. Comput. Ind. Eng. 2017, 110, 231-241. [CrossRef]

10. Varela, M.L.R.; Putnik, G.D.; Manupati, V.K.; Rajyalakshmi, G.; Trojanowska, J.; Machado, J. Collaborative manufacturing based on cloud, and on other I4.0 oriented principles and technologies: A systematic literature review and reflections. Manag. Prod. Eng. Rev. 2018, 9, 90-99. [CrossRef]

11. Varela, M.L.R.; Putnik, G.D.; Manupati, V.K.; Rajyalakshmi, G.; Trojanowska, J.; Machado, J. Integrated Process Planning and Scheduling in Networked Manufacturing Systems for I4.0: A review and framework proposal. Wirel. Netw. 2019, 27, 1587-1599. [CrossRef]

12. Varela, M.L.R.; Ribeiro, R.A. Distributed manufacturing scheduling based on a dynamic multi-criteria decision model. In Recent Developments and New Directions in Soft Computing; Springer: Cham, Switzerland, 2014; pp. 81-93.

13. Canadas, N.; Machado, J.; Soares, F.; Barros, C.; Varela, L. Simulation of cyber physical systems behaviour using timed plant models. Mechatronics 2018, 54, 175-185. [CrossRef]

14. Putnik, G.D.; Škulj, G.; Vrabič, R.; Varela, M.L.R.; Butala, P. Simulation Study of Large Production Network Robustness in Uncertain Environment. CIRP Ann. Manuf. Technol. 2015, 64, 439-442. [CrossRef]

15. Rodič, B. Industry 4.0 and the new simulation modelling paradigm. Organizacija 2017, 50, 193-207. [CrossRef]

16. Varela, M.L.R.; Aparício, J.N.; Silva, S.C. A Web-based application for manufacturing scheduling. In IASTED International Conference on Intelligent Systems and Control; ACTA Press: Salzburg, Austria, 2003; pp. 400-405. ISBN 0889863555.

17. Varela, M.L.R.; do Carmo Silva, S. An ontology for a model of manufacturing scheduling problems to be solved on the web. In International Conference on Information Technology for Balanced Automation Systems; Springer: Boston, MA, USA, 2008 ; pp. 197-204.

18. Alves, C.; Putnik, G.D.; Varela, M.L.R. How Environment Dynamics Affects Production Scheduling: Requirements for Development of CPPS Models. FME Trans. 2021, 49, 827-834. [CrossRef]

19. Eijnatten, F.V.; Putnik, G.D. Chaos, complexity, learning, and the learning organization: Towards a chaordic enterprise. Learn. Organ. 2004, 11, 418-429. [CrossRef]

20. Lee, J.; Bagheri, B.; Kao, H.A. A cyber-physical systems architecture for industry 4.0-based manufacturing systems. Manuf. Lett. 2015, 3, 18-23. [CrossRef]

21. Putnik, G.D.; Pabba, S.K.; Manupati, V.K.; Varela, M.L.R.; Ferreira, F. Semi-Double-loop machine learning based CPS approach for predictive maintenance in manufacturing system based on machine status indications. CIRP Ann. Manuf. Technol. 2021, 70, 365-368. [CrossRef]

22. Shah, V.; Putnik, G.D. Machine learning based manufacturing control system for intelligent Cyber-Physical Systems. FME Trans. 2019, 47, 802-809. [CrossRef]

23. Li, J.Q.; Yu, F.R.; Deng, G.; Luo, C.; Ming, Z.; Yan, Q. Industrial internet: A survey on the enabling technologies, applications, and challenges. IEEE Commun. Surv. Tutor. 2017, 19, 1504-1526. [CrossRef]

24. Liao, Y.; Loures, E.D.F.R.; Deschamps, F. Industrial Internet of Things: A systematic literature review and insights. IEEE Internet Things J. 2018, 5, 4515-4525. [CrossRef]

25. Costa, J.; Ávila, P.; Bastos, J.; Pinto-Ferreira, L. A New Simple, Flexible and Low-Cost Machine Monitoring System. DYNA 2021, 96, 640-646. [CrossRef]

26. Manyika, J.; Chui, M.; Brown, B.; Bughin, J.; Dobbs, R.; Roxburgh, C.; Hung Byers, A. Big Data: The Next Frontier for Innovation, Competition, and Productivity; McKinsey Global Institute: Washington, DC, USA, 2011. 
27. Prades, L.; Romero, F.; Estruch, A.; García-Domínguez, A.; Serrano, J. Defining a methodology to design and implement business process models in BPMN according to the standard ANSI/ISA-95 in a manufacturing enterprise. Procedia Eng. 2013, 63, 115-122. [CrossRef]

28. Fonseca, L. The EFQM 2020 model. A theoretical and critical review. Total Qual. Manag. Bus. Excell. 2021; 1-28, ahead-of-print. [CrossRef]

29. Putnik, G.; Ávila, P. Manufacturing System and Enterprise Management for Industry 4.0 (Editorial). FME Trans. 2021, 49, 769-772. [CrossRef] 